\title{
PERAN PELATIHAN STRATEGI "SMART" DALAM MENINGKATKAN SELF-REGULATED LEARNING (SRL) PADA SISWA SMP
}

\author{
Krishervina R. Lidiawati ${ }^{1}$ \\ Fakultas Psikologi \\ Universitas Pelita Harapan \\ J1. MH. Thamrin Boulevard, Lippo Karawaci, \\ Tangerang 15811, Indonesia \\ 'e-mail:kris4vivien@gmail.com
}

\begin{abstract}
This study examined the role of 'SMART' strategy in enhancing the SelfRegulation Learning (SRL) of Junior High School (SMP) students whose scores were under the school's passing grade (KKM). Self-regulated learning (SRL) is a process in which a learner activates his thought (cognition), feeling (affection), and behavior and which is expected to help students achieve learning objectives systematically (Zimmerman \& Schunk, 2001). SMART (Specific, Measureable, Attention, Realistic, and Time) is a strategy in a SRL process. There were 10 students who participated in this study; 6 males and 4 females. This study used quantitative action research which consisted of two cycles in each of which the researcher measured and evaluated the findings. Using the different paired sample t-test, the result of the first cycle showed that there was no significant change in the participants' self-regulation $(t=1.476, p>.05)$. In the second cycle, it was also shown that there was no significant change of SRL score in post-test 1 and post-test $2(t=0.152, p>.05)$.
\end{abstract}

Keywords: Self-regulated learning; social cognitive theory; adolescence.

\begin{abstract}
Abstrak-Penelitian ini mengkaji peran pelatihan strategi 'SMART' dalam meningkatkan Self-regulated learning (SRL) pada siswa SMP yang memiliki nilai di bawah Kriteria Ketuntasan Minimal (KKM). Self-regulated learning (SRL) adalah suatu proses di mana seorang peserta didik mengaktifkan pikirannya (cognition), perasaannya (affect), dan perilaku (behavior) secara sistematis yang berorientasi pada pencapaian tujuan pembelajaran (Zimmerman \& Schunk, 2001). SMART (Specific, Measurable, Action, Realistic, dan Time) merupakan strategi dalam pembentukan SRL. Jumlah partisipan dalam penelitian ini adalah 10 orang yang terdiri dari 6 laki-laki dan 4 perempuan. Penelitian ini menggunakan metode kuantitatif action research. Penelitian ini terdiri dua siklus, pada masing-masing siklus dilakukan pengukuran untuk mengevaluasi hasil penelitian. Hasil penelitian pada siklus pertama dengan uji beda paired sample t-test menunjukkan tidak adanya perubahan regulasi diri yang signifikan pada partisipan $(t=1.476, p>.05)$. Pada
\end{abstract}


siklus kedua juga menunjukkan tidak adanya perubahan skor SRL secara signifikan pada post-test 1 dan post-test $2(t=0.152, p>.05)$.

Kata kunci: Self-regulated learning; teori kognitif sosial; remaja.

\section{PENDAHULUAN}

Pendidikan di sekolah melibatkan siswa dan guru. Keberhasilan siswa di sekolah dapat diukur dari prestasi akademik yang diperoleh siswa (EL-Anzi, 2005). Meskipun proses pendidikan tidak hanya dilihat dari prestasi akademik, pada kenyataannya masyarakat menilai keberhasilan belajar berdasarkan nilai yang diperoleh siswa di sekolah (Ormrod, 2008; Slavin, 2012). Siswa diharapkan dapat melakukan usaha untuk mendapatkan nilai sesuai dengan standar sekolah maupun pemerintah. Oleh karena itu, siswa dituntut giat dalam belajar yang dianggap sebagai tugas dan tanggung jawabnya. Belajar merupakan proses yang terdiri dari input, proses, dan output (Ormrod, 2008; Slavin, 2012).

Zimmerman (1990) menyatakan bahwa seorang siswa akan memperoleh prestasi belajar yang baik jika mampu memiliki kesadaran belajar, bertanggung jawab dan mengetahui cara belajar yang efisien. Zimmerman menggunakan istilah self-regulated learner atau seorang siswa yang belajar dengan regulasi diri. Seorang self-regulated learner mengambil tanggung jawab terhadap kegiatan belajar dan mengambil alih otonomi untuk mengatur dirinya. Mereka mampu menetapkan tujuan dan masalahmasalah yang mungkin akan dihadapinya dalam mencapai tujuan-tujuannya, mengembangkan standar tingkat kesempurnaan dalam pencapaian tujuan dan mengevaluasi cara yang paling baik untuk mencapai tujuannya sehingga siswa yang mampu melakukan regulasi dalam belajar memperoleh prestasi yang lebih baik dibandingkan siswa yang tidak melakukan regulasi diri (Woolfolk, 2008; Zimmerman, 2002; Zimmerman \& Schunk, 2001a).

Setiap siswa yang mampu melakukan pengaturan diri dalam belajar diharapkan mampu mengikuti pelajaran dan ulangan harian dengan baik sehingga cenderung memperoleh nilai sesuai dengan potensi yang dimiliki. Namun pada kenyataannya, terdapat siswa yang memiliki motivasi rendah dalam belajar sehingga prestasi akademiknya rendah (Balduf, 2009; Zimmerman \& Schunk, 2001a). Selain kurangnya motivasi dalam berprestasi, siswa cenderung melakukan penundaan dalam pengerjaan tugas dan tidak mampu mengatur waktu sehingga tugas-tugas sekolah tidak terselesaikan (Pajares \& Schunk, 2001; Schunk \& Zimmerman, 2001b). Selain itu, siswa yang memiliki strategi dalam belajar dengan melakukan perencanaan (planning) dan memiliki manajemen waktu yang baik terbukti memiliki 
prestasi yang lebih baik daripada siswa lain yang memiliki kemampuan kognitif yang sama, tetapi tidak memiliki planning dan manajemen waktu (Santrock, 2011; Zumbrunn, Tadlock, \& Roberts, 2011).

Sejalan dengan penelitian di atas, berdasarkan wawancara terhadap asisten kepala sekolah (P.K.S. Balukh, komunikasi pribadi, 29 Juli 2013) di salah satu sekolah swasta Bekasi menyatakan bahwa siswa yang memiliki nilai di bawah KKM bukan karena kemampuan kognitif yang kurang, tetapi kurang dapat mengatur diri untuk belajar di rumah. Misalnya siswa cenderung mengabaikan waktu belajar di rumah, kurang latihan mengerjakan soal, tugas ataupun PR yang sudah diberikan oleh guru mata pelajaran. Salah satu strategi dalam SRL adalah membuat goal dalam proses belajarnya (Zimmerman, 2002; Zimmerman \& Schunk, 2001a). Prestasi siswa cenderung rendah karena kurang memiliki tujuan dalam belajar. Penyebab lainnya yaitu kurang adanya kontrol dari orangtua dan tidak memiliki jam belajar yang konsisten di rumah (Woolfolk, 2008; Zimmerman, 2002; Zimmerman \& Schunk, 2001). Mereka cenderung menghabiskan waktu dengan menonton televisi, bermain games di handphone atau di komputer, berkomunikasi di jejaring sosial, dan melakukan kegiatan lain yang tidak berhubungan dengan sekolah. Ketika pelajaran berlangsung, beberapa siswa kurang aktif dalam mengikuti pelajaran dan cenderung melakukan atau memerhatikan hal lain selain guru yang mengajar; misalnya berdiskusi dengan orang lain, menggambar atau sekedar mencorat-coret buku, melamun, dan bahkan tidur dalam kelas.

Fakta di lapangan tersebut sejalan dengan ketentuan dalam Undang-Undang Republik Indonesia Nomor 20 Tahun 2003 tentang Sistem Pendidikan Nasional bahwa guru juga melakukan analisis soal untuk mengkaji tingkat kesukaran soal (Badan Standar Nasional Pendidikan [BSNP], 2013). Setiap sekolah juga memiliki kebijakan bahwa soal ulangan juga harus disesuaikan dengan kisi-kisi ulangan yang diberikan kepada siswa. Ketentuan remedial teaching dan remedial test tersebut memiliki dampak yang positif dan negatif. Siswa cenderung kurang memiliki rasa tanggung jawab dalam menjalankan ujian yang seharusnya dikerjakan maksimal. Ketidaklulusan siswa atau pun prestasi yang rendah bukan karena tidak mampu secara kognitif tetapi kurang adanya motivasi belajar (Cobb, 2003; Schunk \& Zimmerman, 2012). Motivasi siswa yang rendah berdampak pada meningkatnya jumlah peserta remedial pada tiap-tiap mata pelajaran tidak terkecuali mata pelajaran UN. Hal ini menimbulkan keprihatinan bagi peneliti yang juga bekerja sebagai guru BK di salah satu sekolah swasta. Oleh karena itu, diperlukan pelatihan Self-Regulated Learning (SRL) bagi siswa yang memiliki kemampuan kognitif pada taraf rata-rata, tetapi hasil belajarnya belum mampu mencapai standar sekolah atau masih di bawah Kriteria Ketuntasan Minimal (KKM). 
Pelatihan SRL ini diawali dengan mendorong individu untuk memiliki dan mencapai tujuan yang telah ditetapkan yang ditandai dengan timbulnya afektif (perasaan) dan reaksi untuk mencapai tujuan (Santrock, 2011; Schunk \& Zimmerman, 2012). Guru dan orangtua berperan dalam pembentukan SRL (Slavin, 2012). Peran yang dapat dilakukan adalah dengan membantu peserta didik memahami dan memiliki keterampilan dalam mengatur diri secara metakognitif, motivasi, dan perilakunya untuk aktif dalam memperoleh pengetahuan dan keterampilan yang dikenal dengan istilah Self-Regulated Learning (Zimmerman \& Schunk, 2001; Zimmerman \& Schunk, 2012). Pembentukan sikap regulasi diri dalam belajar meliputi secara kognitif, afektif (motivasi), dan perilaku serta membutuhkan pembiasaan sehingga terbentuk sikap disiplin diri (Zimmerman \& Schunk, 2001; Zumbrunn, Tadlock, \& Roberts, 2011).

SRL merupakan proses belajar mengatur diri sendiri, di antaranya adalah self-generation dan pemantauan diri (self-monitoring) dalam berpikir, perasaan, dan perilaku-perilaku untuk mencapai tujuan (Santrock, 2011; Zimmerman \& Schunk, 2001). Self-regulated learner adalah siswa yang secara metakognitif, motivational, dan behavioral merupakan peserta aktif dalam proses belajar mereka sendiri (Zimmerman, 1998; Zimmerman \& Schunk, 2001a).

Salah satu aplikasi SRL telah dibuktikan oleh Corte dan Lucia (dalam Zimmerman \& Schunk, 2001) pada peserta didik secara efektif membantu siswa sekolah dasar kelas 5 sampai sekolah menengah bahkan universitas untuk melakukan regulasi diri pada pengetahuan dan keterampilan matematika. SRL telah dibuktikan secara empiris efektif mendorong siswa untuk dapat mencapai tujuan akademik meliputi keterampilan membaca, menulis, matematika, dan keterampilan berbicara (Schunk \& Zimmerman, 2001; Zimmerman, 2002). Penerapan pelatihan SRL juga telah terbukti efektif membantu siswa dalam meningkatkan prestasi akademik di sekolah dari peserta didik usia sekolah dasar (Ho, 2004) bahkan usia remaja pada siswa sekolah menengah atas (Zumbrunn, Tadlock, \& Roberts, 2011). Selain itu, SRL digunakan pada beberapa keterampilan seperti membaca dan menulis. Penelitian SRL juga dilakukan pada bidang musik, olahraga, dan ilmu pengetahuan (Zimmerman \& Schunk, 2012). SRL dapat meningkatkan kemampuan siswa dalam mengatur waktu dan menyelesaikan tugas sesuai dengan waktu yang ditentukan (Zumbrunn, Tadlock, \& Roberts, 2011).

Siswa yang aktif mengelola dirinya dalam belajar cenderung memiliki prestasi yang lebih baik di bidang akademik (Cobb, 2003). Salah satu karakteristik yang dimiliki siswa yang menggunakan selfregulated learning (SRL) adalah memiliki keaktifan dalam proses belajar dan memiliki kemampuan untuk mengatur belajarnya (Schunk, Zimmerman, \& Wolters, 1998). SRL merupakan sebuah proses yang terbagi menjadi tiga fase yaitu forethought, performance, dan reflective. Masing-masing fase 
memiliki subproses dan strategi untuk melewati fase tersebut. Ketiga fase tersebut merupakan sebuah siklus, artinya berkelanjutan atau berlangsung terus-menerus sampai mencapai tujuan yang diharapkan atau yang telah ditetapkan.

Siswa yang memiliki kemampuan untuk mengatur dirinya dalam belajar adalah siswa yang secara kognitif, afektif (motivasi), dan perilaku merupakan siswa yang proaktif dalam proses belajar (Schunk \& Zimmerman, 2012). Zimmerman (1990) menyimpulkan bahwa ada tiga aspek dalam self-regulated learning yaitu metakognisi, motivasi, dan perilaku.

Berdasarkan uraian di atas dapat disimpulkan bahwa, secara teoretis, SRL diperlukan siswa dalam mencapai hasil belajar yang optimal. Namun berdasarkan pengalaman penulis sebagai guru BK di salah satu sekolah swasta, penulis menemukan kenyataan di lapangan bahwa terdapat siswasiswi yang secara kognitif memiliki kemampuan rata-rata bahkan di atas rata-rata dibandingkan teman sebayanya kurang memiliki SRL sehingga kurang mampu mengikuti pelajaran sehingga tidak dapat memenuhi standar sekolah. Penelitian-penelitian yang telah diuraikan di atas misalnya pelatihan strategi SRL yang dilakukan Zimmerman (dalam Zimmerman \& Schunk, 2011) pada siswa-siswi yang memiliki prestasi rendah dan kemudian dilatih untuk dapat menetapkan tujuan, membuat perencanaan serta didorong untuk dapat melakukan monitoring terbukti dapat memiliki prestasi yang meningkat dibandingkan sebelumnya. Hal tersebut menunjukkan bahwa salah satu upaya yang dapat dilakukan untuk menangani siswa yang kurang memiliki SRL adalah melalui pelatihan SRL.

Penelitian ini menggunakan strategi SMART yang merupakan singkatan dari Specific, Measurable, Action, Realistic, dan Time. Strategi SMART ini merupakan prinsip dari proses SRL. Specific diambil dari prinsip goal setting dan planning artinya memiliki tujuan dan perencanaan secara spesifik pada fase forethought. Measurable artinya dapat diukur, hal ini tampak dari fase performance berupa selfrecording dan self-observation. Hal ini menunjukkan adanya hasil dari tujuan yang dapat dilihat dan terukur. Action atau tindakan nyata merupakan cakupan dari fase performance. Partisipan diharapkan dapat terlibat dalam tindakan nyata dalam keseharian melalui lembar kerja dan komitmen yang telah disepakati. Realistic yaitu sesuai dengan kenyataan, diharapkan tujuan dan apa yang menjadi evaluasi nantinya disesuaikan dengan kemampuan dan kebutuhan masing-masing individu. Realistic cakupan dari ketiga fase SRL. Time (waktu) yaitu berkaitan lama waktu yang dibutuhkan dalam pengerjaan, pencapaian, dan perbaikan diri untuk mampu menjadi regulator diri.

Penelitian ini dilaksanakan pada siswa kelas VIII yang memiliki taraf kecerdasan rata-rata berdasarkan tes IQ di kelas VII dengan pertimbangan bahwa dengan kecerdasan taraf rata-rata yang dapat diartikan bahwa secara kemampuan kognitif mereka setara dibandingkan anak-anak seusianya 
sehingga diharapkan mereka tidak mengalami kesulitan untuk mencapai nilai KKM. Penelitian ini juga difokuskan pada empat mata pelajaran yang termasuk dalam ujian nasional yaitu Matematika, Bahasa Indonesia, Bahasa Inggris, dan IPA. Berdasarkan pemikiran tersebut, penulis bermaksud mengkaji apakah peran pelatihan strategi SMART dalam meningkatkan Self-Regulated Learning (SRL) pada siswa SMP yang memiliki nilai mata pelajaran di bawah KKM khususnya pada mata pelajaran yang termasuk dalam Ujian Nasional di sekolah KI.

\section{METODE}

\section{Partisipan}

Partisipan dalam penelitian ini adalah remaja awal. Mengacu pada Santrock (2011), remaja awal adalah remaja berusia 11-15 tahun, laki-laki maupun perempuan dan terdaftar sebagai siswa SMP KI memiliki nilai mata pelajaran UN di bawah KKM. Sampel yang dijadikan partisipan penelitian ini adalah murid di sekolah KI yang memiliki rentang usia 11- 15 tahun di kelas VIII sebanyak 10 siswa sesuai dengan tujuan penelitian. Dari ke-10 siswa tersebut terdiri dari 6 laki-laki dan 4 perempuan.

\section{Desain}

Dalam penelitian ini, peneliti menggunakan metode kuantitatif action research. Metode kuantitatif dilakukan dengan mengumpulkan data dan hasil yang diperoleh diolah dengan teknik statistik. Action research merupakan penelitian yang terdiri dari tahapan perencanaan dan pelaksanaan kemudian dilakukan evaluasi untuk perbaikan pada siklus selanjutnya.

\section{Prosedur}

Dalam prosedur penelitian ini terdiri dari persiapan dan pelaksanaan penelitian. Persiapan dalam penelitian ini adalah mempersiapkan kajian teoretis, mengajukan izin kepada pihak sekolah, dan mempersiapkan modul pelatihan dan alat ukur SRL. Pelaksanaan penelitian ini dilakukan sejak bulan Juli sampai Desember 2013. Metode penelitian ini adalah metode kuantitatif action research. Penelitian ini mengukur SRL sebagai pre-test, post-test 1, dan post-test 2. Adapun pemberian pre-test di awal sebelum pelaksanaan pelatihan yang pertama. Pada akhir Pelatihan pertama diberikan posttest 1 dan dilakukan evaluasi pelatihan tahap pertama. Selanjutnya peneliti memberikan pelatihan tahap kedua. Setelah pelatihan kedua selesai maka dilakukan post-test 2. Action research merupakan 
penelitian yang terdiri dari tahapan perencanaan dan pelaksanaan kemudian dilakukan evaluasi untuk perbaikan pada siklus selanjutnya.

\section{Teknik Analisis}

Pengolahan data yang dilakukan oleh peneliti yaitu dengan menggunakan salah satu program SPSS untuk menguji normalitas Kolmogorov-Smirnov. Peneliti kemudian melakukan uji beda $t$-test untuk pre-test dan post-test alat ukur Self-Regulated Learning.

\section{ANALISIS DAN HASIL}

Penelitian dilakukan pada 10 siswa yang merupakan siswa kelas VIII dari SMP KI yang memiliki nilai di bawah KKM pada mata pelajaran UN. Pengolahan data dilakukan dua kali yaitu pre-test dan post-test.

Hasil penelitian pada siklus pertama dengan uji beda paired sample t-test menunjukkan tidak adanya perubahan regulasi diri yang signifikan pada partisipan $(t=1.476, p>.05)$. Pada siklus kedua juga menunjukkan tidak adanya perubahan skor SRL secara signifikan pada post-test 1 dan post-test $2(t=0.152, p>.05)$.

Tabel 1.

Perubahan Skor SRL

\begin{tabular}{ccccc}
\hline No. & Nama & Pre-test & Post-Test 1 & Post-Test 2 \\
\hline 1. & CA & 82.00 & 105.00 & 101.00 \\
2. & EL & 75.00 & 80.00 & 82.00 \\
3. & GO & 87.00 & 86.00 & 94.00 \\
4. & IG & 85.00 & 89.00 & 80.00 \\
5. & IS & 82.00 & 94.00 & 91.00 \\
6. & WS & 84.00 & 81.00 & 85.00 \\
7. & AN & 90.00 & 94.00 & 97.00 \\
8. & CI & 78.00 & 79.00 & 70.00 \\
9. & SR & 90.00 & 97.00 & 105.00 \\
10. & SV & 80.00 & 75.00 & 78.00 \\
\hline
\end{tabular}


Dari data tabel 1 dapat dilihat pada siklus 1 terdapat tujuh partisipan yaitu CA, EL, IG, IS, AN, CI, dan SR yang mengalami peningkatan skor SRL dari pre-test ke post-test 1, sedangkan pada tiga partisipan yaitu GO, WS, dan SV mengalami penurunan skor SRL. Pada siklus 2 yang terdapat enam partisipan yaitu EL, GO, WS, AN, SR, SV mengalami peningkatan skor SRL sedangkan empat partisipan lain mengalami penurunan skor SRL yaitu CA, IG, IS, CI dan SV. Berdasarkan tabel 1. terdapat tujuh partisipan yang mengalami peningkatan skor SRL sebelum (pre-test) dan sesudah (posttest 2) mengikuti pelatihan SRL dalam dua siklus ini. Selain itu, terdapat tiga partisipan yang terus mengalami peningkatan skor SRL baik pada siklus 1 maupun siklus 2 yaitu EL, AN, dan SR.

\section{DISKUSI}

Pelatihan SRL yang dilakukan belum efektif dikarenakan beberapa faktor baik dari situasi partisipan maupun situasi sekolah. Faktor dari partisipan misalnya ketidaksiapan dalam mengikuti proses pelatihan. Pada siklus 1, pelatihan yang dilakukan belum maksimal karena pelatihan dilakukan pada jam istirahat sehingga situasi lingkungan sekolah kurang kondusif dan membuat partisipan kurang nyaman. Faktor lain yang mengurangi kesiapan adalah jam istirahat sudah terpotong dengan tugas yang harus dikerjakan pada siswa sebagai bentuk sanksi karena kelalaian siswa dalam pelajaran yang diikuti. Selain itu, partisipan belum memiliki komitmen dalam mengikuti pelatihan. Ketidaksiapan partisipan dalam menerima informasi dapat menghambat keberhasilan pelatihan yang diberikan. Oleh karena itu, dilakukan perbaikan dalam proses pelatihan untuk setiap sesi dan kesepakatan jadwal atau waktu pertemuan serta komitmen dalam mengumpulkan lembar kerja yang diberikan. Pada awal pelatihan siklus 2 dibacakan jadwal pertemuan sehingga partisipan dapat menyepakati waktu yang telah ditentukan dan menuliskan di agenda masing-masing. Selain itu, peneliti memilih satu orang dari masing-masing kelas untuk menjadi koordinator pelatihan strategi SMART. Koordinator bertugas untuk mengingatkan jadwal pertemuan pelatihan strategi SMART dan memudahkan peneliti untuk berkomunikasi jika terjadi perubahan jadwal pelatihan dikarenakan adanya remedial atau bersamaan dengan program sekolah. Pelatihan SRL akan efektif membentuk perilaku regulasi diri dengan melibatkan aspek kognitif, afektif, dan perilakunya (Santrock, 2011). Hal ini sejalan dengan penggunaan pelatihan SRL pada siswa dengan sistem monitoring yang dilakukan dalam kelompok dengan pendekatan yang melibatkan kognitif dan emosi (Renninger \& Shumar, 2002). Selain itu, self-monitoring dalam diri siswa dapat lebih efektif jika terdapat keterlibatan peran orangtua atau orang yang lebih dewasa ataupun orang-orang sekitar 
sehingga siswa mampu menerapkan strategi-strategi SRL sebagai proses pembentukan dalam diri individu sehingga kelak mampu melakukan regulasi diri dalam belajar secara mandiri (Renninger \& Shumar, 2002; Slavin, 2009; Zimmerman \& Schunk, 2011; Zumbrunn, Tadlock, \& Roberts, 2011). Pada penelitian ini terdapat keterbatasan waktu dalam penyampaian materi strategi SRL yang seharusnya dapat lebih efektif jika dilakukan ke dalam beberapa sesi atau dalam jangka waktu yang lebih lama. Misalnya, pada sesi time management membutuhkan 2 sampai 3 minggu untuk membuat partisipan dapat lebih terampil menerapkan cara mengatur waktu keseharian mereka dengan dibantu adanya mentor atau orang dewasa sebagai pengawas sementara sampai mereka terampil melakukannya sendiri (Nicol \& Macfarlane-Dick, 2006; Zimmerman \& Schunk, 2001).

\section{SIMPULAN DAN SARAN}

\section{Simpulan}

Berdasarkan analisis data yang telah dilakukan mengenai peran pelatihan strategi SMART dalam meningkatkan Self-Regulated Learning (SRL) pada siswa SMP yang memiliki nilai di bawah KKM maka dapat disimpulkan bahwa pelatihan SRL yang diterapkan di SMP KI belum efektif dalam meningkatkan skor SRL. Hal ini dapat dilihat dari data skor kuesioner SRL yang belum mengalami peningkatan secara signifikan pada data post-test 1 dan post-test 2. Di sisi lain, terdapat perubahan perilaku siswa dalam mengikuti proses pembelajaran khususnya mata pelajaran UN. Misalnya tanggung jawab siswa dalam mengerjakan tugas dan tidak pernah absen dalam mengikuti remedial teaching atau pun remedial test. Prestasi siswa pada mata pelajaran UN mengalami peningkatan prestasi belajar dan penurunan jumlah remedial. Hal ini terlihat berkurangnya partisipan dalam mengikuti remedial 1 atau pun remedial 2. Berdasarkan data ulangan mata pelajaran UN terdapat perubahan nilai ulangan harian meskipun tidak secara signifikan.

\section{Saran Teoretis}

Hasil penelitian ini belum menunjukkan efektivitas self-regulated learning pada siswa yang memiliki nilai di bawah KKM. Saran teoretis yang dapat diberikan untuk penelitian selanjutnya adalah hendaknya lebih fokus pada satu dimensi self-regulated learning sehingga dapat menunjukkan efektivitas program yang telah disusun dan dapat melakukan evaluasi secara lebih mendalam. Selain itu, pelatihan berikutnya hendaknya perlu memerhatikan tipe kepribadian, jenis kelamin, dan jumlah partisipan dalam satu kelompok. 


\section{Saran Praktis}

Bagi sekolah dapat disarankan sekolah dapat memberikan agenda sebagai bukti pencatatan adanya pengerjaan PR, tugas, dan ulangan. Bagi guru BK perlu memerhatikan siswa yang memiliki nilai di bawah KKM bukan hanya karena tampilan prestasi di sekolah, tetapi dari berbagai faktor yang memengaruhi kondisi siswa dalam meningkatkan prestasi belajar. Bagi para pembaca diharapkan melalui hasil penelitian ini dapat memiliki pemahaman tentang peranan self-regulated learning dalam membantu meningkatkan prestasi belajar siswa dalam jangka panjang.

\section{REFERENSI}

Balduf, M. (2009). Underachievement among college students. Journal of Advanced Academics, 20(1), 274-294.

Badan Standar Nasional Pendidikan. (2003). Peraturan Badan Standar Nasional Pendidikan. Nomor:0020/P/BSNP/I/2013 tentang prosedur operasi standar penyelenggaraan ujian nasional sekolah menengah pertama/madrasah Tsanawiyah, sekolah Menengah Pertama Luar Biasa, Sekolah Menengah Atas/Madrasah Aliyah, Sekolah Menengah Atas Luar biasa, Sekolah Menengah Kejuruan serta Pendiikan Kesetaraan Program Paket A/ULA, program Paket B/ Wustha, Program paket C, dan Program paket C Kejuruan tahun pelajaran 2012/2013.

Cobb, R. (2003). The relationship between self-regulated learning behaviors and academic performance in web-based courses (Unpublished Dissertation). Faculty of Virginia Polytechnic Institute and State University, USA.

El-Anzi, F. O. (2005). Academic achievement and its relationship with anxiety, self esteem, optimism, and pessimism in Kuwait students. Social behavior and personality, 33(1), 90-104.

Ho, E. S. C. (2004). Self-regulated learning and academic achievement of Hong Kong secondary school students. Education Journal, 32(2), 87-107.

Nicol D., \& Macfarlane-Dick, D. (2006). Formation assessment and self-regulated learning: A model of seven principles of good feedback practices. Studies in Higher Education, 31(2), 199-218.

Ormrod, J. E. (2008). Educational psychology (6th ed.). Upper Saddle River, NJ: Pearson Prentice Hall. 
Pajares, F., \& Schunk, D. H. (2001). Self-beliefs and school success: Self-efficacy, self-concept, and school achievement. In R. Riding \& S. Rayner (Eds.), Self-perception (pp. 239-266). London: Ablex.

Renninger, K. A., \& Shumar, W. (2002). Building virtual communities: Learning and change in cyberspace. Cambrige, UK: Cambridge University Press.

Santrock, J. W. (2011). Educational psychology. Boston, MA: McGraw Hill.

Schunk, D. H., \& Zimmerman, B. J. (2012). Motivation and self-regulated learning: Theory, research and application. New York, NY: Routledge.

Slavin, R. E. (2012). Educational psychology. Englewood Cliffs, NJ: Prentice-Hall, Inc.

Woolfolk, A. (2008). Educational psychology: Active learning edition (10th ed.). Boston, MA: Allyn \& Bacon.

Zimmerman, B. J. (1998). Academic studying and the development of personal skill A self regulatory perspective. Educational Psychologist, 33(2/3), 73-86.

Zimmerman, B. J. (2002). Becoming a self-regulated learner: An overview. Theory into Practice, 41(2), 64-70.

Zimmerman, B. J., \& Schunk, D. H. (2001a). Handbook of self-regulation oflearning and performance. New York, NY: Routledge.

Zimmerman, B. J., \& Schunk, D. H. (2001b). Self-regulated learning and academic achievement (2nd ed.). Mahwah, NJ: Erlbaum.

Zumbrunn, S., Tadlock, J., \& Roberts E. E., (2011). Encouraging self-regulated learning in the classroom: A review of the literature. Metropolitan Educational Research Consortium (MERC) database. Ditemu kembali dari http://www.self-regulation.ca/uploads/5/6/2/6/56264915/ encouraging_self_regulated_learning_in_the_classroom.pdf 